\title{
Active faulting in SW Bulgaria: possible surface rupture of the 1904 Struma earthquakes
}

\author{
Bertrand Meyer, ${ }^{1}$ Rolando Armijo ${ }^{1}$ and Dimitar Dimitrov ${ }^{2}$ \\ ${ }^{1}$ Institut de Physique du Globe de Paris, CNRS - UMR 7578, 4 Place Jussieu 75252 Paris cedex 05, France. Email: meyer@jpgp.jussieu.fr \\ ${ }^{2}$ Institute of Geodesy, Bulgarian Academy of Sciences, 1113, Sofia, Bulgaria
}

Accepted 2001 September 7. Received 2001 September 7; in original form 2001 May 14

\begin{abstract}
Two destructive earthquakes, a main shock preceded by a large foreshock, occurred in 1904 in the Balkan region. These events have long been recognized as the largest earthquakes ever recorded in Europe, and the mainshock was assigned a magnitude up to 7.8. The region affected by the shaking straddles the present border between Bulgaria and the Republic of Macedonia, with the immediate epicentral area close to Krupnik in the Struma valley. Neither the surface break nor the source faults of the 1904 events have yet been identified. Using satellite imagery and field observations, we mapped active faults close to, or within, the epicentral area. The most prominent ones are three 20-35 km long normal faults: the Kocani fault in the eastern part of the Republic of Macedonia, and the two neighbouring Krupnik and Bansko faults in south-west Bulgaria. The latter two are the closest to the immediate epicentral area of the 1904 events. Geologic and morphologic observations allow us to estimate the age of initiation $(\sim 13 \mathrm{Ma})$ and the long-term slip-rate $\left(\sim 0.15 \mathrm{~mm}\right.$ year $\left.{ }^{-1}\right)$ of the Krupnik fault. The onset and rate of faulting suggest that the region experienced a limited amount of stretching ( $<10$ per cent) during the Tertiary, in conflict with the values ( $>100$ per cent) deduced from regional models involving extension on low-angle detachments faults. Along the Krupnik fault we found a recent $2 \mathrm{~m}$-high scarp that may have formed in 1904. A possible rupture of the Krupnik fault compatible with our observations would account for a moment $M_{\mathrm{o}}=2.810^{19} \mathrm{Nm}$ and a magnitude $M_{\mathrm{s}}=6.9$, significantly smaller than the previous estimates.
\end{abstract}

\section{INTRODUCTION}

On 4 April 1904 a main shock, preceded by a large foreshock 23 min earlier, struck the Balkan and North Aegean regions. Their epicentral area is in the western Rhodope, a mountainous region that was then part of the Ottoman empire and now straddles the border between Bulgaria and the Republic of Macedonia (Fig. 1). Strong shaking was widespread, including present-day Bulgaria, Serbia, the Republic of Macedonia, Greece, Hungary, Romania, SW Russia and Turkey (Karnik 1968). The main event has long been considered as the largest shallow earthquake ever recorded instrumentally in Europe. Gutenberg \& Richter (1954) assigned a magnitude of $M 7.5$ to the main shock. Christoskov \& Grigorova (1968) used trace amplitudes recorded at 10 stations in Europe and Russia to calculate $M_{\mathrm{s}} 7.8$ for the mainshock and $M_{\mathrm{s}} 7.3$ for the foreshock. However, no fault and fault break have been described as possible sources for the events. Active faults are poorly identified within the epicentral region and its surroundings. Also at larger scale, the tectonic style, the deformation rates and hence the regional seismic hazard are difficult to assess.
Using satellite imagery and published geological information, we compiled the main active faults in the region. After critical revision of earlier maps, we identified and re-mapped several normal faults within and around the epicentral area. We studied the most prominent faults in the field to evaluate longterm slip-rates and to find evidence for recent reactivation. Using the tectonic observations and the macroseismic and seismological data available, we envision possible scenarios for the 1904 sequence. Finally we discuss the larger-scale tectonic implications in relation with the nearby extensional strains in the Aegean.

\section{REGIONAL TECTONICS AND ACTIVE FAULTING}

The 1904 earthquakes occurred north of the Aegean Sea where several mountain belts merge: the Dinarides, the Hellenides, the Rhodope and the Balkan (Fig. 1). The structural trends are outlined by the topography and by the courses of large rivers, such as the Vardar, the Struma (Strimon), the Mesta (Nestos), 

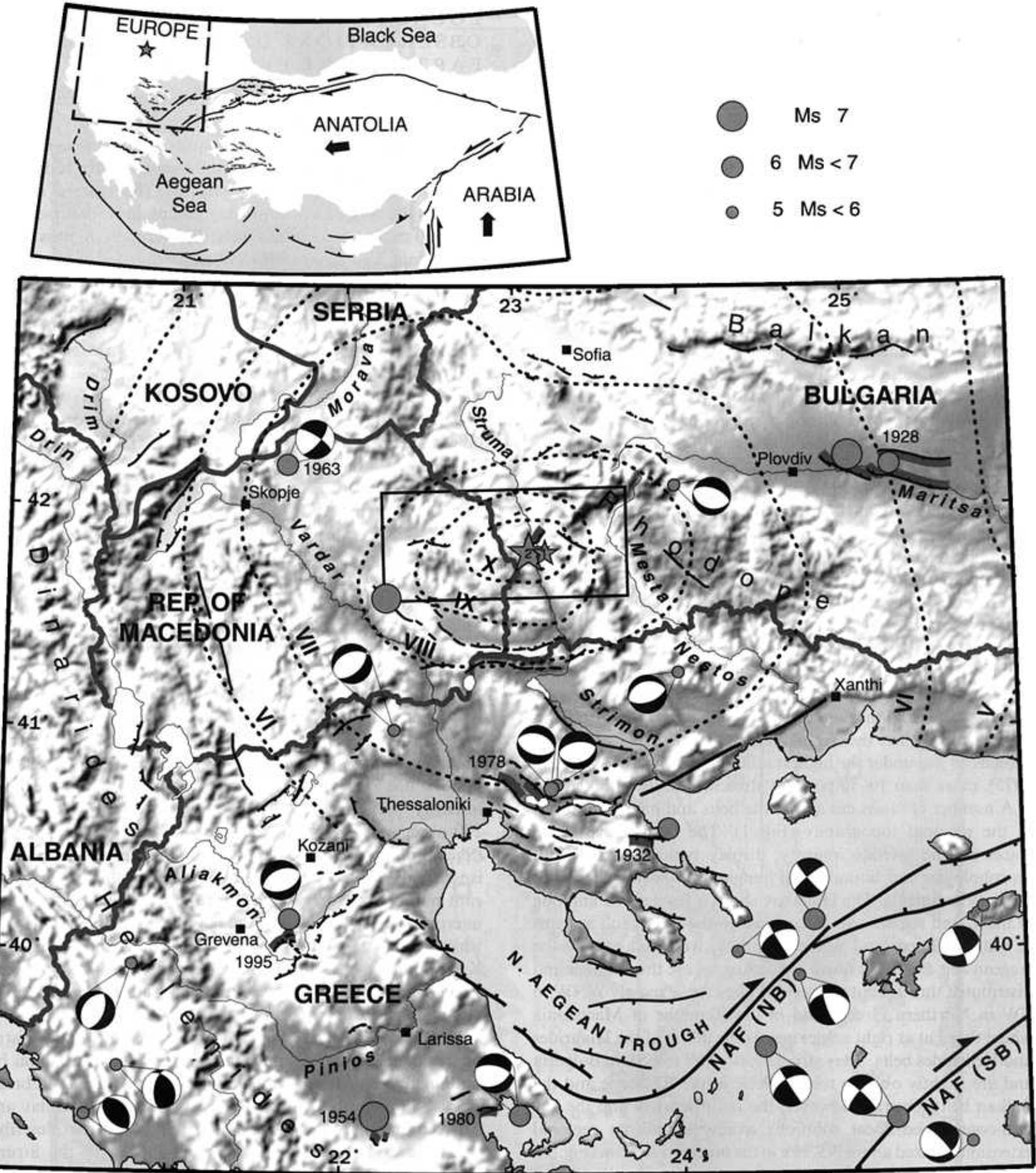

Figure 1. Seismotectonic map of the region struck by the 4 April 1904 Struma earthquakes. Epicentres of the foreshock and main shock (numbered stars) are from Karnik 1968). Isoseismals of the main shock (dotted grey lines, MSK intensity scale) are from Grigorova \& Palieva (1968). Insert locates main shock within the tectonic framework. Active faults compiled from bathymetry (offshore), geological studies and satellite imagery (onshore). Faults associated with earthquake breaks are outlined in grey. Seismicity from the USGS; fault-plane solutions from Harvard Centroid-Moment Tensor catalogue. The background DEM image is from GTOPO 30. Box outlines the area enlarged in Fig. 2.

and the Maritsa. The fabric is almost NS in the Dinarides and in the Hellenides, rather NW-SE in the Vardar suture zone and in the Rhodope, and turns to EW in the Balkan. These belts have formed mainly from late Mesozoic to early Neogene as crustal shortening was taking place between the converging Africa and Eurasia plates (e.g. Dewey et al. 1973). The regional 
transect from the internal to the external zones of the orogen (e.g. Jacobshagen et al. 1978) can be summarized as follows. Precambrian and Palacozoic basement rocks outcrop along the axis of the Balkan and Rhodope belts. In the Rhodope, the basement has been intruded by Tertiary granitoids that crop out in large areas of the massif. South-west of the Vardar suture, fold-and-thrust platform units imbricated with phyllites and ophiolites mark the backbone of the relief in the Dinarides and the Hellenides. Compression prevailed over most of the region until the Neogene and the last shortening event reported in central Bulgaria is of early Miocene age (Zagorcev 1992a)

The region appears now mostly under crustal extension and is thought to be the northernmost part of the Aegean stretched domain (e.g. Jackson \& McKenzie 1988; Armijo et al. 1996; Burchfiel et al. 2000). However, as for the Aegean, the age of the onset of normal faulting, the amount of stretching and the driving mechanisms of the extension remain controversial. Some have proposed high stretching rates and large amounts of crustal thinning, either during a single phase of deformation over the last 5 Ma (Jackson \& McKenzie 1988) or during a polyphased evolution over the last $25 \mathrm{Ma}$ (Lister et al. 1984; Gautier et al. 1993; Jolivet et al. 1994: Burchfiel et al. 2000). Another view has emphasized a two-stage evolution resulting from the recent propagation of the North Anatolian fault into the already slowly extending Aegean domain (Armijo et al. 1996, 1999). The thickness of the crust provides bounds on the amount of extension in different parts of the Aegean. The deepest parts of the Aegean Sea have a crustal thickness of only $20 \mathrm{~km}$ (Makris 1978) and might have experienced more than 100 per cent stretching. Significant stretching is less likely in the eastern and western sides of the Aegean Sea where the crust is $30 \mathrm{~km}$ thick close to the coast and even thickens inland (Tsokas \& Hansen 1995). In the Rhodope, where the crustal thickness averages $35-40 \mathrm{~km}$ and exceeds $48 \mathrm{~km}$ under the highest reliefs (e.g. Foose \& Manheim 1975), more than 10-30 per cent stretching seems unlikely.

A number of faults cut across the belts and have an imprint in the regional topography (Fig. 1). The faults have sharp traces on the satellite imagery, display typical normal fault morphologies and bound small hangingwall basins filled with Tertiary sediments. The faults are short, a few tens of $\mathrm{km}$ long at most, and segmented. In contrast to the large fault systems in central Greece and western Turkey, west and east of the Aegean Sea, the faults north of the Aegean are thus smaller and distributed throughout the region. They strike mostly WNW to EW in Northern Greece and in the Republic of Macedonia where they cut at right angles across the fabric of the Dinarides and Hellenides belts. They strike mostly EW to ESE in Bulgaria and are slightly oblique to the fabric in the Rhodope and the Balkan belts. Overall, however, the fault network and the few well-constrained focal solutions available indicate regional extension directed about NS, like in the northern Aegean (Fig. 1).

A number of these faults have ruptured during destructive earthquakes with clear surface breaks. For instance, two recent events (Thessaloniki, $M_{\mathrm{s}}=6.4$ in 1978; Grevena, $M_{\mathrm{s}}=6.6$ in 1995) ruptured $10-15 \mathrm{~km}$ long normal fault segments in Northern Greece (e.g. Mercier et al. 1979; Meyer et al. 1996). Two larger events (Plovdiv, $M=6.8$ and $M=7$ in 1928) ruptured somewhat longer $(20-25 \mathrm{~km})$ fault segments along the Maritsa valley in North-eastern Bulgaria (Richter 1958). Surprisingly, no significant surface break was documented for the presumably larger 1904 events, although significant faults can be identified in the area most severely shaken.

\section{LOCAL FAULTS AND PREVIOUS OBSERVATIONS OF THE 1904 EARTHQUAKE EFFECTS}

Three conspicuous normal faults lie close to the epicentral area (Figs 1 \& 2): the Kocani fault in eastern Republic of Macedonia and the Krupnik and the Bansko faults in south-west Bulgaria. The Kocani fault has a total length of about $25 \mathrm{~km}$ and is made of two approximately EW segments. The eastern segment outlines the base of a north-facing mountain front dissected by $300-500 \mathrm{~m}$ high triangular facets. The Krupnik fault is almost $20 \mathrm{~km}$ long and strikes NE-SW on both sides of the Struma River. The fault bounds a NW facing mountain front with 400-metre-high facets. The Bansko fault locates immediately east of the Krupnik fault and has a total length of $30 \mathrm{~km}$. The fault outlines the northern edge of the Pirin and marks a $800 \mathrm{~m}$ high NE facing scarp made of prominent triangular facets separated by wine glass valleys. The Kocani fault is more distant than the Krupnik and the Bansko faults from the epicentres of the 1904 shocks. The Krupnik fault is the only one that locates entirely within the epicentral area.

The damage in the epicentral area were reported soon after the events by Hoernes (1904) and Watzof (1905). Based on these original reports, several isoseismal maps were proposed. Kirov \& Palieva (1961) published two isoseismal maps, one for the foreshock and one for the mainshock. However, the time interval between the foreshock and the mainshock (23 min) seems too short to discriminate between their respective effects, and the damage probably result from the combined effects of the two shocks. Grigorova \& Palieva (1968) ascribed most of the damage to the mainshock and published a more reliable isoseismal map of the main event. The map was subsequently reproduced by Shebalin et al. (1974), who added the intensities observed in each locality; information used by Grigorova and Palieva but lacking in their original publication. The lower intensity contours $(\mathrm{I}<\mathrm{VII})$ are constrained by more than 200 observations distributed throughout a widespread region (Shebalin et al. 1974). The higher intensity contours, like the isoseismals VII and X, are fairly well constrained by a significant number of observations, but the isoseismal IX has been interpolated. Specifically, the area of maximum intensity $(I=X)$, which demarcates the immediate epicentral region centred on Krupnik, relies on intensities determined for about twenty villages built on various types of soil and bedrock in either mountains or valleys (Fig. 2).

Hoernes (1904) and Watzof (1905) described many disturbances of the ground surface within the epicentral region but nothing that could be unambiguously ascribed to a fault break. They both reported numerous open cracks in the flat area between the towns of Simitli and Krupnik. Hoernes described cracks several hundred meters long, parallel to the Struma River and possibly due to slumping and landsliding of the river banks. More interestingly, he described EW cracks across the road between Simitli and Krupnik. Many years later, following these observations and the testimonies of old villagers who witnessed the events, Kirov \& Palieva (1961) pointed out the possible occurrence of several approximately EW cracks, ascribing to them lengths of tens of meters and a location along the mountain front south of Krupnik and across the Struma River. Kirov \& Palieva (1961) also deduced that the Struma River was dammed by the time of the earthquake and that a temporary lake formed east of Krupnik. 


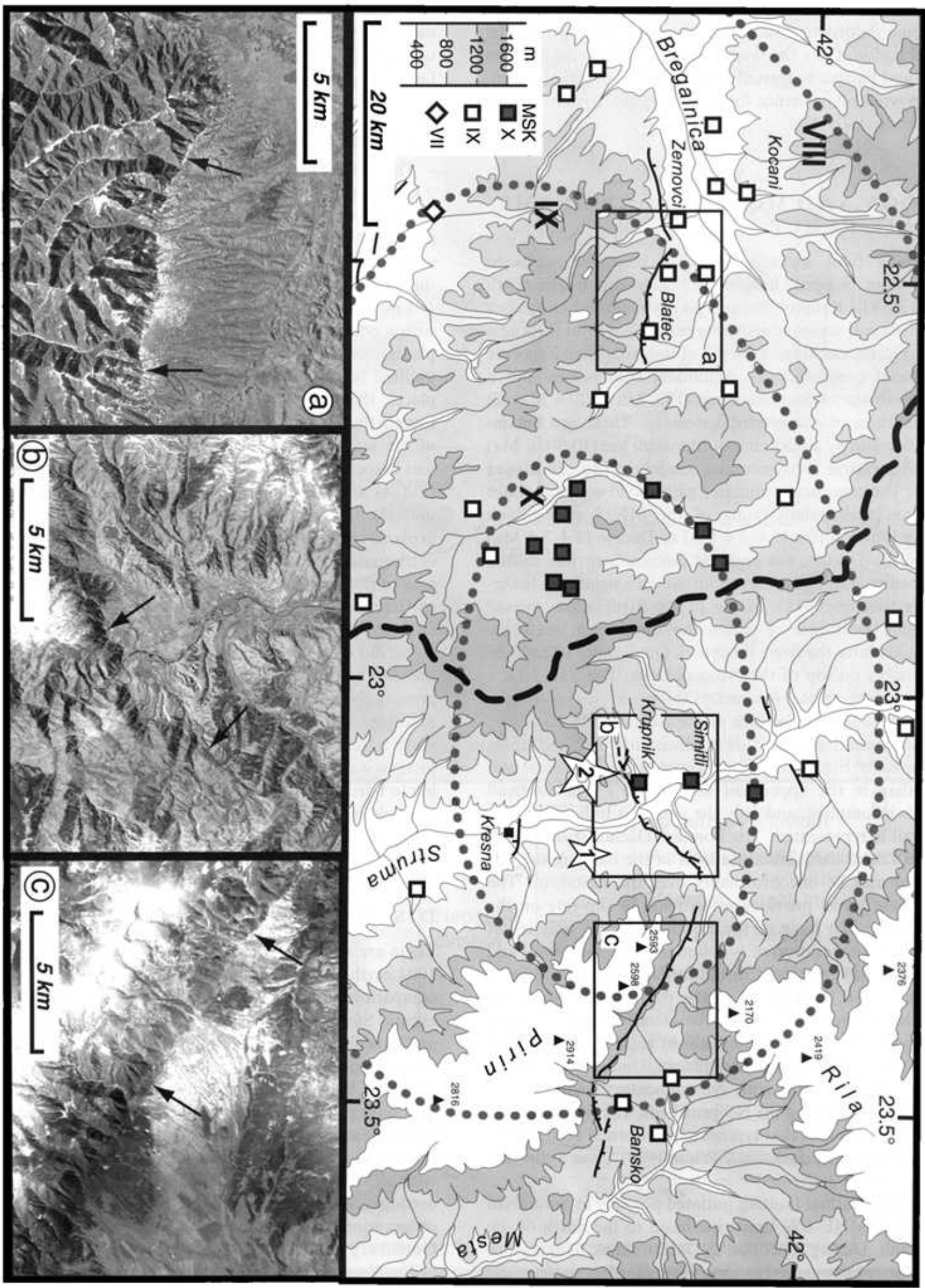

Figure 2. Active faults around the 1904 epicentral area. The faults were mapped with SPOT imagery, aerial photographs and field observations. Three normal faults have a clear imprint in the morphology: the Kocani fault in eastern Republic of Macedonia and the Krupnik and the Bansko faults in south-western Bulgaria. Isoseismals as in Fig. 1 and MSK intensities from Shebalin et al. (1974). Topography from $1: 500.000$ scale map (BAGS 1976). Boxes outline the frames of enlarged SPOT images below. (a) The eastern segment of the Kocani fault between Zernovci and Blatec. Snow preserved at the base of the relief outlines the fault trace. (b) 'I he Krupnik fault across the valley of the Struma River. (c) I'he western segment of the Bansko fault outlined by prominent triangular facets north of Pirin mountains. 
The contemporary information indicates that landslides and non-tectonic deformation were widely distributed within the epicentral region. Only the later and rather imprecise account by Kirov and Palieva suggested the occurrence of a fault scarp. The scarp would have hence formed along the Krupnik fault, across the Struma valley.

\section{GEOLOGY AND MORPHOLOGY OF THE KRUPNIK FAULT.}

The Krupnik fault separates footwall basement rocks to the south from Neogene hangingwall sediments to the north (Figs 2 \& 3). The Krupnik basin is an asymmetric half-graben filled with several sedimentary units reaching a total thickness of $750 \mathrm{~m}$ (Geological Map of the PR of Bulgaria 1990; Zagorcev 1992b). Basal conglomerates containing coal beams and a pollen assemblage of Sarmatian age (13.8 Ma to $10.6 \mathrm{Ma}$ ) fill the irregularities of the eroded basement. These are unconformably overlain by a thick unit of Maeotian age (10.6-6.6 Ma) starting with coarse conglomerates grading up to sandstones and clays. The sequence terminates with fluvio-conglomerates that contain mammalian fauna of the MN13 zone which indicates a Late Pontian (6.6-5.4 Ma) to Dacian (5.4-3.6 Ma) age. Since the Dacian, the regional environment has shifted from depositional to erosional conditions with significant lowering of the base-level. The course of the Struma has incised the Neogene sediments of which the uppermost levels are about $200 \mathrm{~m}$ above the river. Patches of Quaternary terraces lie unconformably on top of the Neogene beds. The terraces are made of conglomerates a few meters thick and were emplaced during the post-Dacian incision of the basin.

The hangingwall sequence dips consistently SE and abuts against the fault (Fig. 3). Dips are steeper in the lowermost unit $\left(20-25^{\circ}\right)$ than in the uppermost one $\left(10-15^{\circ}\right)$. The footwall sequence is incomplete, and only the youngest unit seen in the hangingwall is represented. The Pontian-Dacian sediments in the footwall have the same attitude as in the hangingwall but are uplifted and lie unconformably over the basement. The offset of these layers provides an estimate of slip-rate on the Krupnik fault. The base of the Pontian-Dacian unit is cut by the fault at an elevation of $\sim 450 \mathrm{~m}$ in the hangingwall and is found at $\sim 1050 \mathrm{~m}$ height in the footwall, which implies a throw-rate of $\sim 0.1 \mathrm{~mm} \mathrm{yr}^{-1}$ in the past $6 \mathrm{Myr}$. Assuming uniform throw-rate, the $\sim 1.3 \mathrm{~km}$ basement step would have formed since about $13 \mathrm{Ma}$. This age is in good agreement with the age of the basal sediments in the basin. Uniform slip during $13 \mathrm{Ma}$ is also compatible with synsedimentary tectonics and with the progressive tilt of the Neogene beds. Taking an average fault dip of $45^{\circ}$, a value that typifies active normal faults in the seismogenic crust (e.g. Jackson \& White 1989), gives a slip-rate of $\sim 0.15 \mathrm{~mm} \mathrm{yr}^{-1}$.

In summary, normal faulting initiated possibly in Sarmatian times isolating a NE-SW lacustrine basin to the north of the Krupnik fault. During Maeotian to Dacian times, hangingwall subsidence may have caused progressive infill of the basin while footwall uplift may have prevented significant accumulation of sediments on it. After deposition of the Dacian sediments, erosional conditions have prevailed. Morphologic evidence attest to continuing fault activity during the Quaternary (Fig. 4). It is north-east of the Struma River where the fault morphology is the clearest and more impressive (Fig. 4). The mountain front is more than $300 \mathrm{~m}$ high, made of trapezoidal facets and capped by the Pontian-Dacian sediments. Natural sections of the fault plane are exposed along tributaries that incise the facets (Fig. 5a). Near the surface, the fault is steep and dips $\sim 60^{\circ}$ to the WNW in all the sections. In some places the quaternary conglomerates and/or young debris slope are sliced within the fault zone, attesting to recent episodes of faulting.

The evidence for the most recent fault reactivation is found $2 \mathrm{~km}$ north of the Struma River, where a $20^{\circ}$-sloping-facet covered with turf, bushes and trees is disrupted by a bare scarp (Fig. 5b). The scarp is seen from a distance and can be traced across rivers, rills and intervening ridges for about $4 \mathrm{~km}$ along the mountain front (Fig. 4b). The scarp is about $2 \mathrm{~m}$ high and 1-3 m wide. It is made of weathered and schistosed bedrock with a colluvium of washed material along its base. In several places, steep parts $\left(40-50^{\circ}\right)$ remain visible at the contact between uplifted basement and the colluvium below (Fig. 5c). In a few places, the scarp is made of a steep $\left(60^{\circ}-70^{\circ}\right)$ cemented fault breccia that marks a bedrock free face (Fig. 5d). The continuity of the scarp across rills and ridges indicates that it is not a scar associated with a landslide. Given the length of the scarp (Fig. 4) and the shape of the offset slope (Fig. 5e) it is also unlikely that the scarp could be man made. Thus, the simplest explanation is that the scarp resulted from fault slip during an earthquake. Its freshness, location with respect to the epicentral area of the 1904 events and the absence of other large historical earthquakes in the region strongly suggests that the observed fault scarp formed in 1904 .

We did not find a similar scarp along the fault south-west of the river but smaller, discontinuous and more eroded scarps are present there at a few places along the mountain front. For example, we have observed a $20 \mathrm{~m}$ long, 1-2 m high, smooth scarp across a small fan located close to the place where the Struma was temporarily dammed after the 1904 events according to Kirov \& Palieva (1961). In contrast to the Krupnik fault, our field investigation did not reveal evidence for recent scarps along the Bansko fault.

\section{DISCUSSION}

There are three clear active faults in the epicentral area of the 1904 earthquakes. They have lengths between 20 and $35 \mathrm{~km}$, compatible with $M_{\mathrm{s}} \approx 7$ earthquakes, but not with much larger events. Steep, localized fault planes bounding distinct scarps are typical of actively extending regions. Hidden faults have never been clearly documented in such regions. Blind faulting seems to be a feature of compressional and not extensional regions (e.g. Stein \& Yates 1989). For example, the large normal faulting earthquakes $(M=6.5)$ that struck Greece and Western Turkey in the last 30 years have all occurred on steep faults with clear morphology. It is therefore unlikely that the 1904 earthquake occurred on a large hidden normal fault and our observations cast doubt on the large magnitude estimated by Gutenberg \& Richter (1954).

The Kocani fault lies outside the area of maximum intensity (X). The Bansko fault is partly inside the area of maximum intensity whereas the Krupnik fault is located entirely inside. Evidence for an earthquake scarp that can be attributed to the 1904 event is found only along the Krupnik fault. The scarp might have formed during the foreshock, but the main event should therefore have been associated to a larger break on 


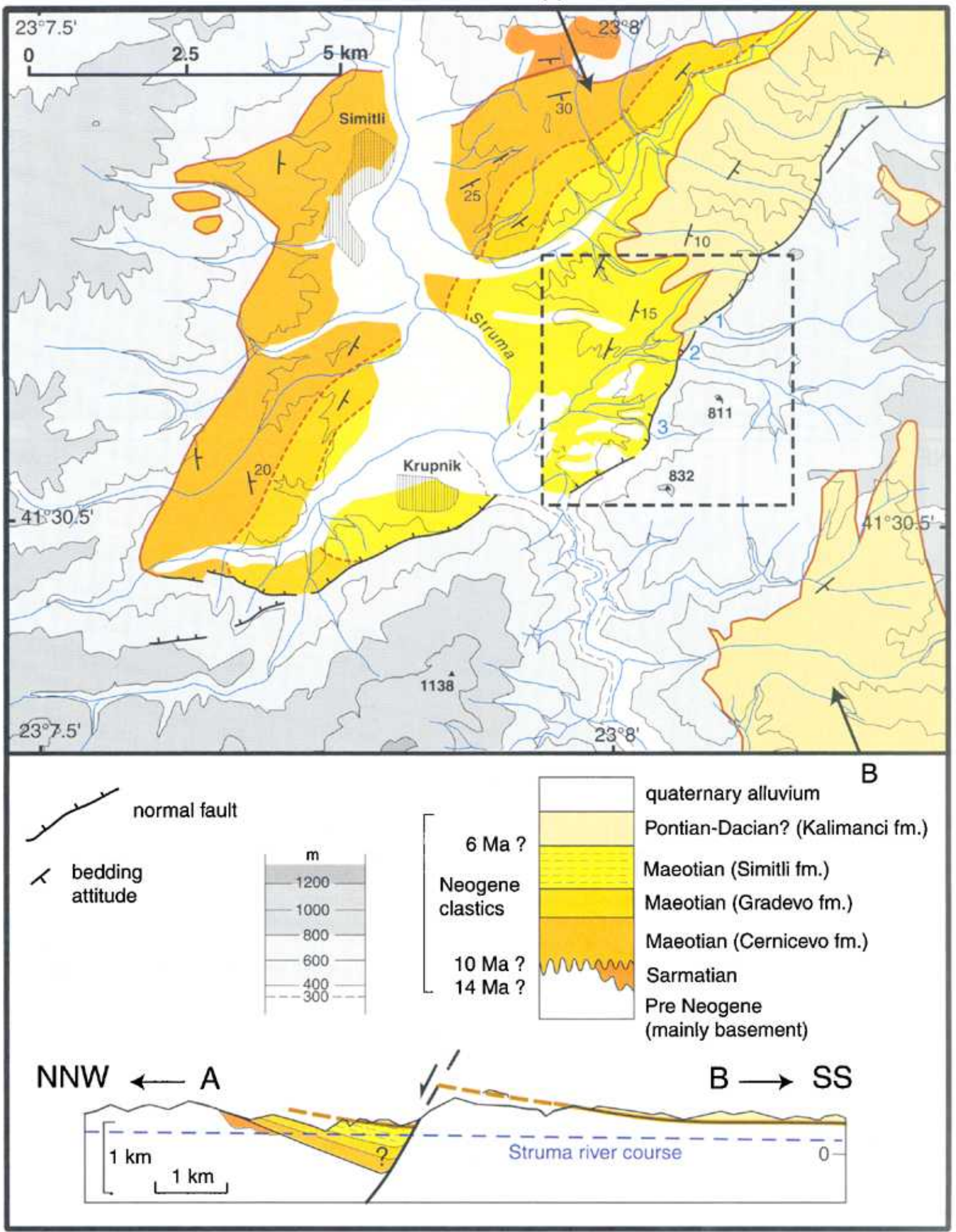

Figure 3. Simplified Cenozoic geology of Krupnik area (central box in Fig. 2). The NE-SW striking Krupnik fault isolates Neogene hangingwall strata (to the north) from a footwall basement high (to the south). The canyon of Struma River is incised in the footwall block. The topography is from $1: 50.000$ scale map (BAGS 1976) and the geology is simplified from 1:100.000 scale geological map (Razlog sheet, edited by R. Marinova and I. Zagorcev, Geological map of the PR of Bulgaria 1990). Arrows A to B locate the simplified section below. The box outlines the frame of the SPOT enlargement in Fig. 4. The dashed blue line on the section is the projection of Struma river bed. 

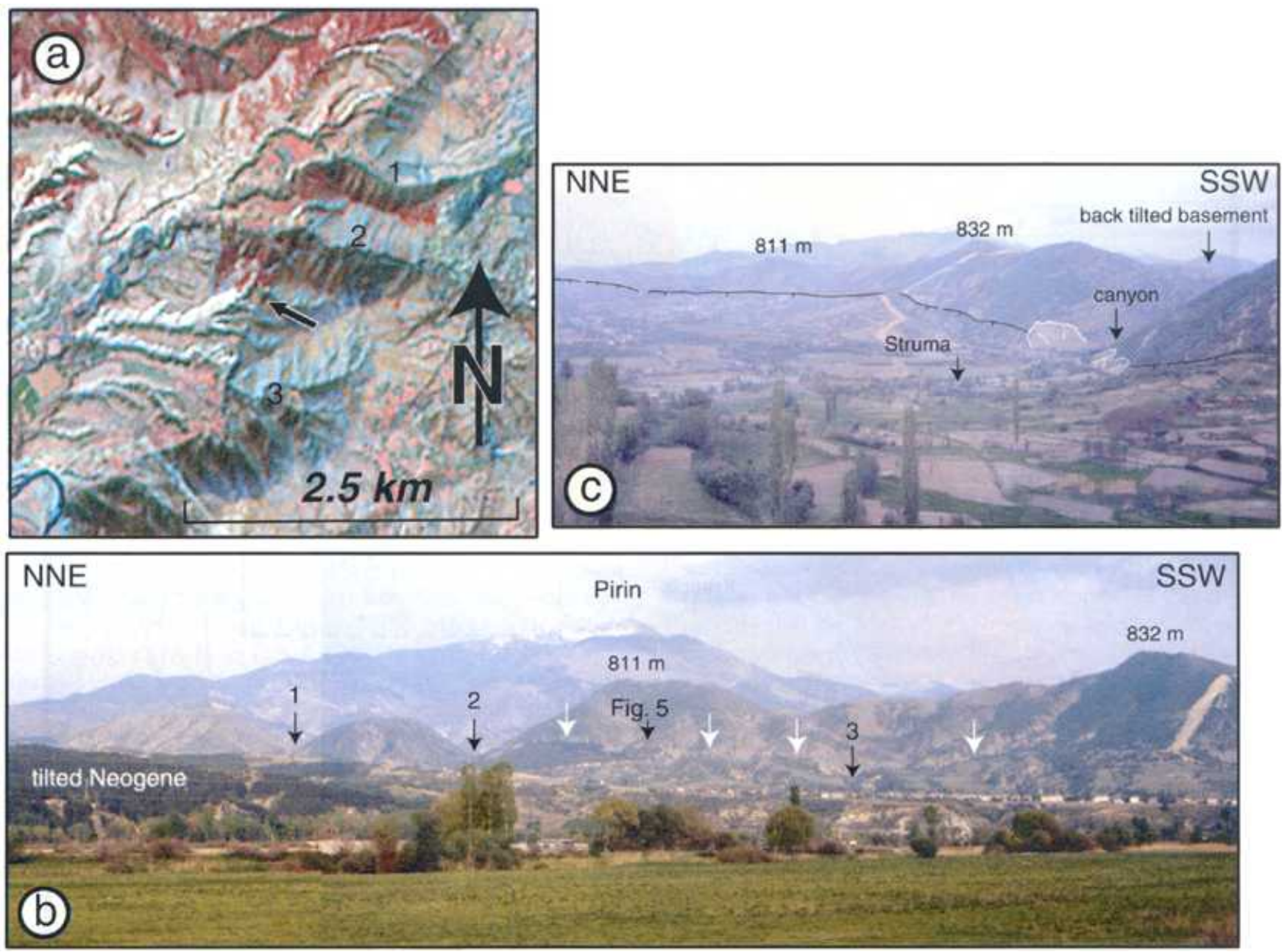

Figure 4. Morphological observations of the Krupnik fault. (a) An enlargement of the SPOT image showing the clearest part of the fault trace at the base of a NW facing cumulative scarp. Numbers indicate rivers identified in (b). (b) View to SE of the faulted landscape east of the Struma River, The Neogene basin is in the foreground. The fault trace (white arrows) runs at the base of the cumulative scarp, about $400 \mathrm{~m}$ high. (c) View to SE of the fault scarp across the Struma River. Note river canyon across footwall basement.

the Bansko or the Kocani faults. Our observations make this hypothesis improbable, and we conclude that the Krupnik fault probably hosted the mainshock of the 1904 sequence. Assuming an average fault dip of $45^{\circ}$, a $15 \mathrm{~km}$ thick seismogenic crust, and a slip of $2 \mathrm{~m}$ on $\mathrm{a} \approx 20 \mathrm{~km}$ long fault, compatible with the field observations yields a seismic moment of $M_{\mathrm{o}}=2.810^{19}$ $\mathrm{Nm}$. Taking the empirical relationship between $M_{\mathrm{o}}$ and $M_{\mathrm{s}}$ (Ekström \& Dziewonski 1988), this corresponds to $M_{\mathrm{s}}=6.9$, a value significantly smaller than the early estimates. This value is close to $M_{\mathrm{s}} \sim 7.1$ listed by Abe \& Noguchi (1983b) in their uniform catalogue for worldwide shallow events with $M_{\mathrm{s}}=7$. Abe and Noguchi $(1983 a, b)$ demonstrated that the magnitudes of early twentieth century events were significantly overestimated because they were calculated from records made with undamped seismometers. These authors accounted for this bias by applying a systematic correction. More recently, Ambraseys (2001) reappraised the instrumental data concerning the 1904 events. Confirming that the mainshock was overestimated by at least 0.3 units of magnitude, he obtained a value of $M_{\mathrm{s}}=7.2$. Thus both the tectonic observations and the recent seismological studies require a significant downsizing of the 1904 events.
The discrepancy between our estimate and the revised instrumental values can be explained by the uncertainties of each approach. The variance of surface wave measurements for an event with a particular scalar moment is about 0.2 magnitude units (Ekström \& Dziewonski 1988). The observations of scarps at the surface may underestimate rupture length, slip and thus seismic moment (e.g. Wells \& Coppersmith 1994). For instance, a possible $25 \mathrm{~km}$-long rupture with average slip of $4 \mathrm{~m}$ on the Krupnik fault would account for an event with $M_{\mathrm{s}}=7.1$.

The Krupnik fault probably hosted the 1904 mainshock, but it is difficult to ascertain the source of the foreshock. The foreshock might have taken place also on the Krupnik fault, on a deep portion of the fault plane. This would have required a seismogenic crust unusually thick $(>15 \mathrm{~km})$ for which there is no compelling evidence. The foreshock could also have taken place either on the Bansko fault or on the Kocani fault. The first possibility implies that the rupture did not reach the surface or that the surface break has disappeared during the last 90 years. The hypothesis of a break along the Kocani fault has not been tested in the field. However, examples of earthquakes triggered by stress transfer between contiguous faults would favour 

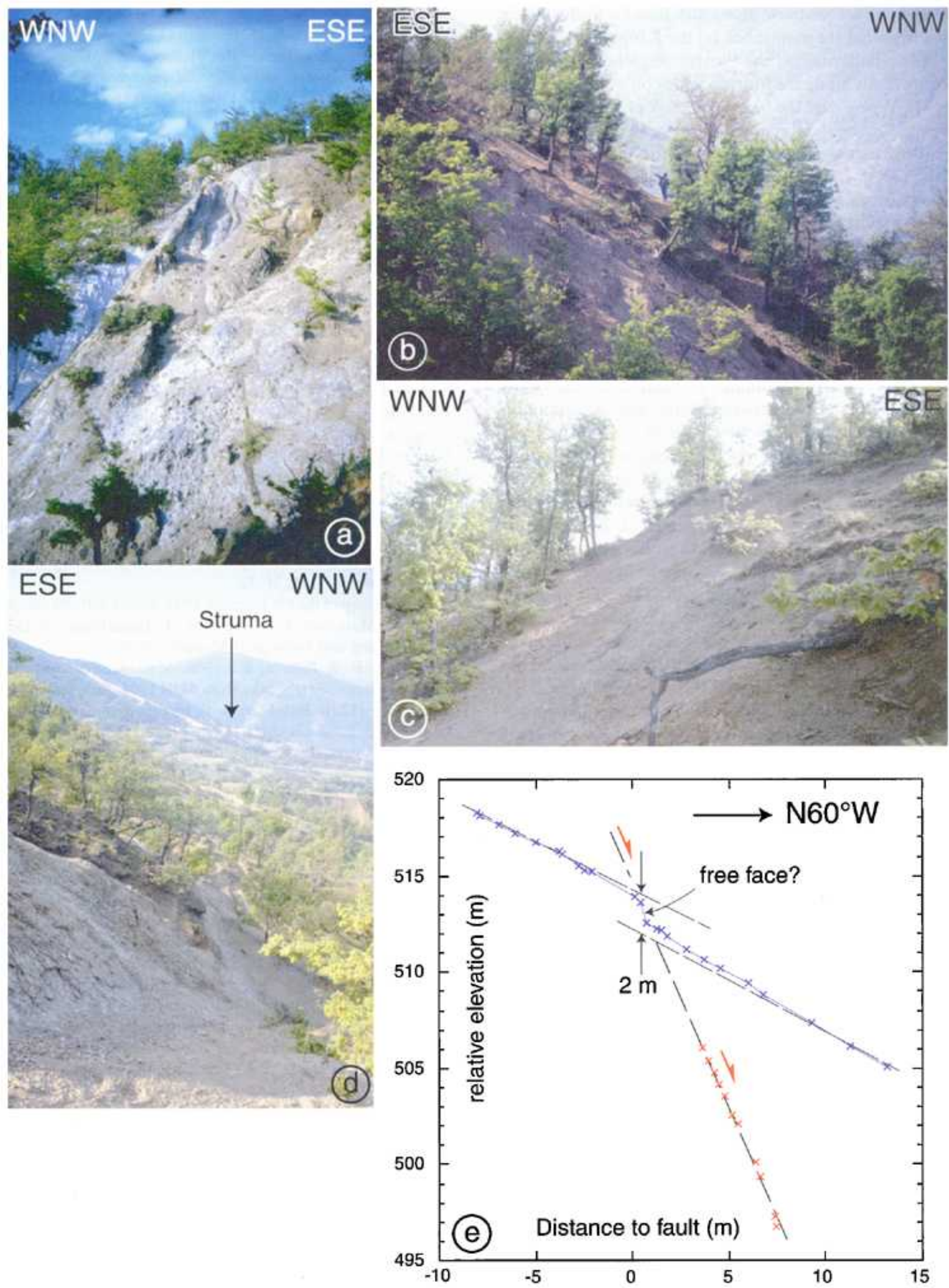

Figure 5. Field observations of the Krupnik fault (location in Fig. 4). (a) A natural section of the fault plane dipping $60^{\circ}$ to the WNW, separating basement (right) from Neogene sandstones (left). (b) View to SSW of the 2-m-high scarp along the fault trace. (c) View to NNE of the scarp, $150 \mathrm{~m}$ south-westwards from (b). The base of the scarp coincides with the fault trace and separates brecciated basement (right) from colluvial material (left). (d) Detail of the scarp across small rills and intervening ridges. The steeper part of the scarp is made of cemented fault breccia and could be a remnant of the original free-face associated with the 1904 event. (e) Profiles showing fault plane attitude and slope offset. Measurements of the slope (blue crosses) and fault plane (red crosses, taken in an adjacent creek) projected along strike on a section perpendicular to the fault. Accuracy of measurements is about $2 \mathrm{~cm}$. 
the hypothesis of a foreshock along the Bansko fault, which could have triggered the mainshock on the Krupnik fault. This scenario bears similarities to the Plovdiv sequence that broke neighbouring faults along the Maritsa valley on 14 and 18 April 1928 (Fig. 1). Where ever the foreshock took place, the modest long-term slip-rate on the Krupnik fault suggests that moderate and infrequent earthquakes characterise the regional seismic behaviour.

Our observations also have implications for the extensional history of the Northern Aegean domain. The normal faults in northern Greece and Bulgaria have similar morphologic and geological imprints (Fig. 1). They barely modify the topography and bound small hangingwall basins filled with late Cenozoic sediments as in the Krupnik basin. The longterm throw-rate $\left(\sim 0.1 \mathrm{~mm} \mathrm{yr}^{-1}\right)$ and onset of deformation ( $\sim 13 \mathrm{Ma})$ deduced for the Krupnik fault are possibly similar in other similar faults. Assuming 10 such faults across a $300 \mathrm{~km}-$ long N-S section between Sofia and Thessaloniki (Fig. 1), and average fault dips of $45^{\circ}$, gives $\sim 1 \mathrm{~mm} \mathrm{yr}^{-1}$ of extension. This estimate is in good agreement with the few GPS measurements available in Bulgaria and northern Greece indicating less than $2 \mathrm{~mm} \mathrm{yr}^{-1}$ of NS extension across the region (e.g. McClusky et al. 2000; Kahle et al. 2000). Extrapolating these rates over the past $15 \mathrm{Ma}$ would account for at most 5-10 per cent of stretching across the region, a value compatible with the thickness of the crust $(35-50 \mathrm{~km})$ under the Rhodope. This contrasts with the view that normal faulting on low-angle detachments faults has been responsible for a considerable thinning of the crust north of and within the North Aegean Sea during the past $25 \mathrm{Myr}$ (e.g. Gautier et al. 1999 and references therein). Specifically, our observations are in conflict with the large amount of stretching (100 per cent) inferred by Dinter et al. (1995) in the southern Rhodope between $16 \mathrm{Ma}$ and $3 \mathrm{Ma}$.

\section{ACKNOWLEDGMENTS}

We thank Nick Ambraseys for providing a preprint of his work in advance to publication. We acknowledge reviews by N. Ambraseys and R.S. Yeats. This work was supported by CNRS and MAE. This is IPGP contribution number 1790.

\section{REFERENCES}

Abe, K. \& Noguchi, S., 1983a. Determination of magnitudes for large shallow earthquakes 1898-1917, Phys. Earth planet. Inter., 32, 45-59.

Abe, K \& Noguchi, S 1983b Revision of magnitudes for large shallow earthquakes 1898-1912, Phys. Earth planet. Inter., 33, 1-11.

Ambraseys, N.N., 2001. The Kresna earthquake of 1904 in Bulgaria. Annali Geofisica, 44, 95-117.

Armijo, R., Meyer, B., Hubert, A. \& Barka, A., 1999. Westwards Propagation of the North Anatolin Fault into the Northern Aegean: Timing and kinematics, Geology, 27, 267-270.

Armijo, R., Meyer, B., King, G.C.P., Rigo, A. \& Papanastassiou, D., 1996. Quaternary evolution of the Corinth Rift and its implications for the evolution of the Aegean, Geophys J. Int., 126, 11-53.

BAGS (Bulgarian Army Geographical Service), 1976. Topographic map of Bulgaria, Scale, 1, 500.000, Simitli and Padech sheets.
Burchfiel, B.C.R., Nakov, T., Tzankov \& Royden, 2000. Cenozoic extension in Bulgaria and Northern Greece: the northern part of the Aegean extensional regime. In: Tectonics and Magmatism in Turkey and the Surrounding Area, Special Publications, 173, E. Bozkvet, J.A. Winchester \& J.D.A. Piper, Editors, pp. 325-352, Geological Society, London.

Christoskov, L. \& Grigorova, E., 1968. Energetic and space-time characteristics of the destructive earthquakes in Bulgaria after 1900, Bull. Inst. Geoph, Sofia, XII, 79-107 (in Bulgarian, with English summary).

Dewey, J.F., Pitmann, W.C., Ryan, W.B.F. \& Bonnin, J., 1973. Plate tectonics and the evolution of the Alpine system, Geol. Soc. Am. Bull., 84, 3137-3180.

Dinter, D.A., Macfarlane, A., Hames, W., Isachsen, C., Bowring, S. \& Royden, L., 1995. U-PB and ${ }^{40} \mathrm{Ar} /{ }^{39} \mathrm{Ar}$ geochronology of the Symvolon granodiorite: Implications for the thermal and structural evolution of the Rhodope metamorphic core complex, northeastern Greece, Tectonics, 14, 886-908.

Ekström, G. \& Dziewonski, A.M., 1988. Evidence of bias in estimation of earthquake size, Nature, 332, 319-323.

Foose, R.M. \& Manheim, F., 1975. Geology of Bulgaria. A Review, Am. Assoc Petrol. Geol. Bull., 59, 303-335.

Gautier, P., Brun, J.P. \& Jolivet, L., 1993. Ductile crust exhumation and extensional detachments in the central Aegean (Cyclades and Evvia islands), Tectonics, 12, 1180-1194.

Gautier, P., Brun, J.P., Moriceau, R., Sokoutis, D., Martinod, J. \& Jolivet, L., 1999. Timing, kinematics and cause of Aegean extension: a scenario based on a comparison with simple analogue experiments, Tectonophysics, 315, 31-72.

Geological map of the PR Bulgaria, 1990. Scale 1:100000 (Razlog Sheet), eds R. Marinova \& I. Zagorcev, I, Department of Geophysical Prospecting and Geological Mapping, Sofia.

Grigorova. E. \& Palieva, K., 1968. Macroseismic characteristics of the destructive Earthquake from 04.04 1904, Bull, Inst. Geoph., Sofia, XII, 109-112 (in Bulgarian, with English summary).

Gutenberg, B. \& Richter, C.F., 1954. Seismicity of the Earth and Associated Phenomena, 2nd edn, Princeton University Press, Princeton, NJ.

Hoernes, R., 1904. Makedonische erdbeden vom 4, April 1904, Mitteilungen der Erdbeben - Kommission der Kaiserlichen. Akademie der Wissenschaften in Wien, Neue Folge, XXIV, Wien.

Jackson, J.A. \& McKenzie, D.P., 1988. The relationship between plate motions and seismic tensors, and the rate of active deformation in the Mediterranean and Middle East, Geophys. J. Int., 93, 45-73.

Jackson, J.A. \& White, N.J., 1989. Normal faulting in the upper continental crust: observations from regions of active extension, J. Structural Geol., 11, 15-36.

Jacobshagen, V. Dürr, S. Kockel, R. Kopp, K.O. Kowalczyk, G. Berckhemer, H. Buttner, 1978. Structure and geodynamic evolution of the Aegean region, in Alps, Apennines, Hellenides. Stuttgart Inter-Union Commission on Geodynamics, Sci. rept 38, eds Closs, H., Roeder, D. \& K. Schmidt, pp. 537-564., E. Scweizerbart' she-Verlagsbuchhandlung, Stuttgart.

Jolivet, L., Brun, J.P., Gauthier, P., Lallemant, S. \& Patriat, M., 1994. $3 \mathrm{D}$-kinematrics of extension in the Aegean region from the early Miocene to the present, insights from the ductile crust, Bull. Soc. Géol. France, 165, 195-209.

Kahle, H.S., Cocard, M., Peter, Y., Geiger, A., Reilinger, R., Barka, A. \& Veis, G., 2000. GPS-derived strain rate field within the boundary zopnes of the Eurasion, African, and Arabian plates, J. Geophys. Res., 105, 23 353-23 370.

Karnik, V., 1968. Seismicity of the European Area, Part 1, Academy of Sciences, Praha.

Kirov, K. \& Palieva, K., 1961. Seismic activity of the Struma valley, Bull. Inst. Geoph, Sofia, II, 57-93, (in Bulgarian with English summary).

Lister, G.S., Banga, G. \& Feenstra, A., 1984. Metamorphic core complexes of Cordilleran type in the Cyclades, Aegean Sea, Greece, Geology, 12, 221-225. 
Makris, J. 1978. The crust and upper mantle of the Aegean region from deep seismic soundings, Tectonophysics, 46, 269-284.

McClusky, S.C., et al. 2000. Global Positioning System constraints on plate kinematics and dynamics in the eastern Mediterranean and Caucasus, J. Geophys. Res., 105, 5695-5719.

Mercier, J.L., Mouyaris, N., Simeakis, C., Roundoyanni, T. \& Angelidhis, C., 1979. Intraplate tectonics: a quantitative study of the faults activated by the 1978 Thessaloniki earthquakes, Nature, 278, 45-48.

Meyer, B., et al. 1996. The 1995 Grevena (Northern Greece) earthquake: fault model constrained with tectonic observations and SAR interferometry, Geophys. Res. Letter, 23, 2677-2680.

Richter, C.F., 1958. Elementary Seismology, San Francisco, Freeman.

Shebalin, N.V., Karnik, V. \& Hadzievski, D. 1974 Catalogue of Earthquakes, Atlas of Isoseismal Maps, UNDP-UNESCO Survey of the Seismicity of the Balkan Region, Skopje.
Stein, R.S. \& Yeats, R.S., 1989. Hidden earthquakes, Scientific American, 260, 48-57.

Tsokas, G.N. \& Hansen, R.O., 1995. Study of the crustal thickness and the subducting lithosphere in Greece from gravity data, $J$. Geophys. Res., 102, 20 585-20 597.

Watzof, S., 1905. Tremblements de Terre En Bulgarie, no. 5, Liste des Tremblements de Terre observés pendant l'année 1904, Tsentr. Meteor. stan., Sofia.

Wells, D.L. \& Coppersmith, K.J., 1994. New empirical relationships among magnitude, rupture lenght, rupture width, rupture area, and surface displacement, Bull. seism. Soc. Am., 84, 974-1002.

Zagorcev, I.S., 1992a. Neotectonics of the central parts of the Balkan Peninsula: basic features and concepts, Geolgicshe Rundschau, 81, 635-654.

Zagorcev, I.S., 1992b. Neotectonic development of the Struma (Kraistid) lineament, southwest Bulgaria and northern Greece, Geol. Mag., 129, 197-222. 